\title{
PEMBANGUNAN LINK PENELUSURAN KEBUTUHAN FUNGSIONAL DAN KODE SUMBER BERDASARKAN KEDEKATAN SEMANTIK
}

\author{
Djoko Pramono $^{1}$, Siti Rochimah ${ }^{2}$ \\ ${ }^{1}$ Jurusan Teknik Informatika, Universitas Brawijaya, Malang \\ ${ }^{2}$ Jurusan Teknik Informatika, Fakultas Teknologi Informasi, ITS Surabaya \\ Email: ${ }^{1}$ djoko.jalin@ub.ac.id, ${ }^{2}$ siti@its-sby.edu
}

\begin{abstract}
Abstrak
Link penelusuran membantu pengembang dalam memahami perangkat lunak yang tidak memiliki dokumen perancangan yang lengkap seperti pada kode sumber terbuka. Dalam kode sumber, suatu method mewakili suatu aksi yang dilakukan untuk menyelesaikan suatu kebutuhan fungsional. Pada penelitian ini diusulkan suatu metode untuk membangun link penelusuran antara kebutuhan fungsional dan kode sumber menggunakan pemrosesan bahasa alami dan kedekatan semantik. Kedekatan semantik ditentukan berdasarkan WordNet dan metode perhitungan Wu-Palmer. Pemrosesan bahasa alami dilakukan pada semua deklarasi method dalam kode sumber. Selanjutnya dihitung kedekatan semantik antara kebutuhan fungsional dengan hasil pemrosesan bahasa alami untuk menentukan method-method yang merupakan link penelusuran. Metode ini membantu menemukan bagian mana dari kode sumber yang menjalankan suatu kebutuhan fungsional, serta meningkatkan keakuratan dalam membangun link penelusuran antara kebutuhan fungsional dan kode sumber.
\end{abstract}

Kata kunci : link penelusuran, kedekatan semantik, pemrosesan bahasa alami.

\begin{abstract}
Traceability link helps developers to understand the software that does not have a complete design document as in open source software. In the source code, a method represents an action performed to complete a functional requirement. This research proposed a method to build links between functional requirement and source code using natural language processing and semantic relatedness. Semantic relatedness is determined based on WordNet and the method of calculation by Wu-Palmer. Natural language processing is done on all method declarations in the source code. Further semantic similarity computed between functional requirement and the results of natural language processing to determine the method-method which is traceability link.This method helps locate which parts of the source code that runs a functional requirement, as well as improve the accuracy in building links between functional requirements andsource code.
\end{abstract}

Keywords : traceability link, semantic similarity, natural language processing.

\section{Pendahuluan}

Penelusuran kebutuhan adalah kemampuan untuk menjelaskan dan mengikuti jalannya suatu kebutuhan dalam arah maju maupun mundur (Gotel, 1994). Link penelusuran membantu pengembang untuk mengerti hubungan antara dokumendokumen yang dihasilkan selama proses pengembangan perangkat lunak. Link penelusuran antara dokumen kebutuhan dan kode sumber sangat membantu dalam proses pengembangan dan pemeliharaan perangkat lunak. Dalam proses pengembangan dan pemeliharaan perangkat lunak, pengembang melakukan perubahan pada kode sumber akan tetapi sering melupakan untuk memperbarui dokumen-dokumen yang menyertai kode sumber untuk mempersingkat waktu pengembangan karena dituntut oleh tenggat waktu yang singkat(Ali, 2011). Selama proses pengembangan, link penelusuran antara artifak-artifak perangkat lunak bisa menjadi tidak valid 
karena tidak diperbarui sesuai dengan perubahan yang terjadi pada kode sumber perangkat lunak(Hayasi, 2010). Karena itu diperlukan suatu metode untuk membangun link penelusuran kebutuhan yang cepat dan akurat. Link penelusuran juga berguna jika pengembang menggunakan perangkat lunak yang tidak memiliki dokumen perancangan yang lengkap seperti pada kode sumber terbuka. Dalam proses pengembangan perangkat lunak kadang diperlukan perangkat lunak sumber terbuka. Banyak perangkat lunak sumber terbuka tidak menyertakan dokumen perancangan secara lengkap. Demikian juga pada proses pengembangan perangkat lunak menggunakan metode agile, tidak menyertakan dokumen pengembangan yang detail.

Beberapa metode penemuan kembali informasi(information retrieval/IR) digunakan untuk membangun link penelusuran antara dokumen kebutuhan dengan kode sumber, antara lain VSM(vector space model)(Antoniol, 2000), LSI(latent semantic index)(Marcus dan Meletic, 2003), JS(Jensen Shannon)(Abadi, 2008) dan LDA(Latent Dirichlet Allocation)(Oliveto, 2010). Pendekatan IR menghitung kemiripan tekstual antara kode sumber dengan dokumen kebutuhan, semakin tinggi kemiripan tekstual kemungkian besar kedua artifak mengandung konsep yang sama dan dianggap saling berhubungan. Ali(2012) melakukan penelitian dengan membandingkan penemuan link penelusuran menggunakan metode IR pada beberapa studi kasus dan mendapatkan nilai precision dan recall yang rendah. Nilai precision dan recall dipengaruhi antara lain oleh kualitas dan besarnya kode sumber. Penelitian yang dilakukan Eaddy(2008) menggabungkan IR dengan jejak eksekusi untuk meningkatkan akurasi.

Penelitian menggunakan analisa natural language processing(NLP) pada kode sumber dilakukan oleh David
Sheperd(2006) untuk menemukan pasangan kata kerja(verb) dan kata benda(direct object) dalam deklarasi method. Penelitian yang dilakukan A. Mahmoud(2012) menambahkan dokumen eksternal yaitu Wikipedia sebagai referensi untuk menghitung nilai kedekatan semantik antar kata. Penelitian lain dilakukan Hayashi(2010) menggunakan ontologi sebagai domain pengetahuan untuk menentukan bobot hubungan antar method dalam kode sumber. Kelemahan metode tersebut adalah perlu dibangun ontologi secara manual untuk setiap domain permasalahan.

Dalam penelitian ini digunakan abstract syntax tree(AST) dari kode sumber dan proses pengurai(parsing) untuk mengidentifikasi setiap deklarasi method dalam kode sumber. Langkah berikutnya adalah melakukan ekstraksi menggunakan pemrosesan bahasa alami pada method signature. Selanjutnya menghitung kedekatan semantik antara hasil parsing method signature terhadap kebutuhan fungsional untuk menemukan link penelusuran. Penggunaan pemrosesan bahasa alam(Natural Language Proceessing/NLP) dan kedekatan semantik diharapkan bisa menemukan hubungan antara dua konsep yang berbeda berdasarkan suatu domain pengetahuan. Salah satu contoh domain pengetahuan yang digunakan dalam penelitian ini adalah WordNet(Fellbaum, 2005). Sedangkan untuk menentukan kedekatan semantik antar kata dapat menggunakan rumus yang diusulkan oleh $\mathrm{Wu}$ Palmer(1994). Wu-Palmer menilai kedekatan dua kata menggunakan relasi dan kelompok yang sama(least common subsumer, LCS) dalam WordNet. WordNet digunakan sebagai domain pengetahuan untuk menentukan kedekatan semantik antara konsep dari kebutuhan dan kode sumber. Dari penelitian ini diharapkan akan menghasilkan link antara kebutuhan dengan method yang mengimplementasikan kebutuhan tersebut. 


\section{Tinjauan Pustaka}

\subsection{Penelitian Terkait Link Penelusuran}

Penelitian link penelusuran antara dokumen dan kode sumber menggunakan metode IR berbasis LSI dilakukan oleh Marcus dan Meletic(2003). Penelitian ini menggunakan dua studi kasus perangkat lunak yaitu LEDA dan Albergate. Hasil penelitian pada studi kasus LEDA, hasil pengujian mendapatkan nilai precision sebesar 0.77 pada recall 0.59 sampai nilai precision 0.11 pada recall 1 . Pada kasus Albergate, hasil pengujian mendapatkan nilai precision sebesar 0.44 pada recall 0.45 sampai nilai precision 0.16 pada recall 1. Pada kasus Albergate nilai precision lebih rendah karena dokumen yang digunakan dokumen kebutuhan yang sangat pendek dan tidak ada komentar dalam kode sumber.

Penelitian tentang pembangunan link penelusuran antara dokumen dan kode sumber menggunakan metode IR berbasis LDA dilakukan oleh Oliveto $\operatorname{dkk}(2010)$. Penelitian ini menggunakan dua studi kasus perangkat lunak dengan dataset EasyClinic dan eTour. Penelitian ini membandingkan dua studi kasus tersebut antara metode LDA dengan VSM, LSI dan JS. Hasilnya diperoleh bahwa nilai precision dan recall dari LDA tidak lebih lebih baik dari tiga metode IR tersebut. Tetapi pada kasus eTour, LDA berhasil menemukan link benar yang tidak ditemukan oleh metode IR lainnya sebesar $10 \%$.

Penelitian lain dilakukan oleh David Shepherd dkk(2007) menggunakan Natural Language Processing(NLP). NLP digunakan untuk menemukan verb/kata kerja dan noun/kata benda dalam kode sumber yang saling berhubungan. Pasangan kata kerja dan kata benda, VDO<verb/kata kerja, Direct Object/kata benda> dan lokasinya dalam kode sumber disimpan dalam suatu daftar. Ketika manusia memasukkan queri berupa kata kerja, aplikasi akan memberikan saran berupa pilihan kata benda berdasar pasangan V-DO yang sudah dibangun dari kode sumber.

\subsection{Pemrosesan Bahasa Alami}

Pemrosesan bahasa alami atau Natural Language Processing (NLP) adalah sebuah bidang dalam ilmu komputer dan bahasa yang berkaitan dengan sistem temu kembali (information retrieval/IR) dan berkonsentrasi pada interaksi antara bahasa manusia dan komputer. Salah satu alat yang digunakan dalam pemrosesan bahasa alami adalah Stanford NLP. Stanford NLP adalah sistem yang dikembangkan oleh The Stanford NLP Group dengan fokus penelitian pada sentence understanding, probabilisticparsing dan tagging, biomeicalinformationextraction, grammarintroduction, word sensedisambiguation, dan automaticquestionanswering

(nlp.stanford.edu, 2013). NLP dalam penelitian ini digunakan untuk melakukan tagging dan lematisasi. Part of Speech (POS) tagger adalah proses perangkat lunak untuk membaca teks dalam bahasa alami dan memberikan label dengan menggunakan Part of Speech (POS) seperti kata kerja, kata benda, kata sifat dll. Lemmatisasi bertujuan menghasilkan bentuk dasar dari suatu kata.

\subsection{Kedekatan Semantik}

Langkah-langkah utama dalam mengukur kedekatan semantik adalah dengan memperkirakan keterkaitan kata secara semantik dengan memanfaatkan sejumlah besar domain pengetahuan leksikal dan menggunakan teknik statistik untuk memanfaatkan semua kemungkinan hubungan yang berkontribusi pada kesamaan konsep. Domain pengetahuan biasanya tersedia dalam sumber-sumber eksternal termasuk pengetahuan berbasis linguistik(linguistic knowledge base/LKB) seperti WordNet(Fellbaum, 1998) dan 
pengetahuan berbasis kolaboratif (collaborative knowledge base/CKB). WordNet merupakan kamus (database leksikal) online untuk bahasa inggris. WordNet mendefinisikan sebuah kata menjadi sebuah konsep yang diorganisasi kedalam sejumlah sinonim set(synset)(Miller dkk, 1990). Synset memiki beberapa macam hubungan dengan synset lainnya. Metode-metode untuk menghitung kedekatan semantik antar kata menggunakan WordNet dikategorikan dalam Tabel 1.

Tabel 1. Metode-Metode Kemiripan

Semantic(Shridara dkk, 2006)

\begin{tabular}{|l|l|}
\hline Penulis & Kategori \\
\hline Leacock dan Chadrow & Path based \\
\hline Wu dan Palmer & Path based \\
\hline Jiang dan Conrath & $\begin{array}{l}\text { Information content } \\
\text { based }\end{array}$ \\
\hline Resnik & $\begin{array}{l}\text { Information content } \\
\text { based }\end{array}$ \\
\hline Lin & $\begin{array}{l}\text { Information content } \\
\text { based }\end{array}$ \\
\hline Banerjee dkk & Gloss based \\
\hline
\end{tabular}

Wu-Palmer(1994) mendefinsikan kedekatan semantik sebagai jarak antara dua konsep dalam struktur WordNet dan jarak Least Common Subsumer(LCS).

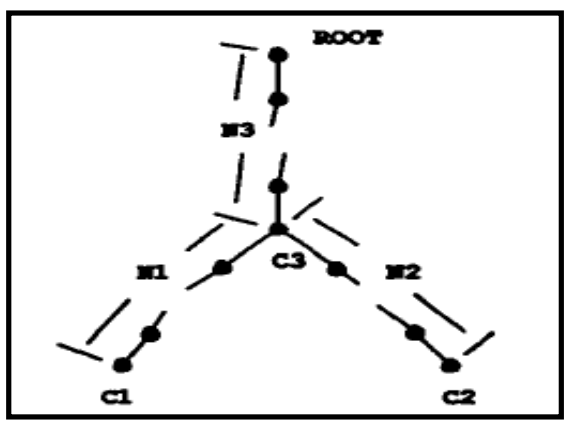

Gambar 1. Ilustrasi Kemiripan Kata (Wu dan Palmer, 1994)

Untuk menghitung kemiripan kata seperti pada ilustrasi Gambar 1, dengan rumus Wu-Palmer ditunjukkan pada Rumus 1. Nilai kemiripan antar dua kalimat $\operatorname{Sen}_{\mathrm{a}}$ dan $\mathrm{Sen}_{\mathrm{b}}$ dapat dihitung menggunakan Rumus 4 yang diusulkan oleh Ming Che Lee(2011).

$$
\begin{aligned}
& \operatorname{sim}(c 1, c 2)=\frac{2 \times N 3}{N 1+N 2+(2 \times N 3)} \\
& \mathrm{NC}_{a b}=\left(\frac{\overrightarrow{N V_{\text {sen_a }}} \cdot \overrightarrow{N V_{\text {sen_b }}}}{\left|\overrightarrow{N V_{\text {sen_a }}}\right| \times \mid \overrightarrow{N V_{\text {sen_b }} \mid}}\right)^{2}
\end{aligned}
$$

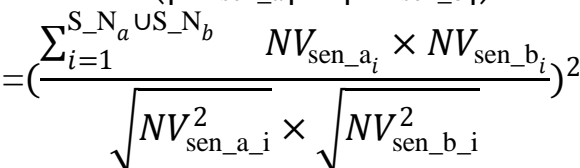

$$
\begin{aligned}
& \mathrm{VC}_{a b}=\left(\frac{\overrightarrow{V V_{\text {sen_a }}} \cdot \overrightarrow{V V_{\text {sen_b }}}}{\left|\overrightarrow{V V_{\text {sen_a }}}\right| \times\left|\overrightarrow{V V_{\text {sen_b }}}\right|}\right)^{2} \\
& =\left(\frac{\sum_{i=1}^{\mathrm{S} \_\mathrm{N}_{a} U \mathrm{US} \_\mathrm{N}_{b}} V V_{\text {sen } \_\mathrm{a}} \times V V_{\text {sen } \_ \text {b }}}{\sqrt{V V_{\text {Sen } \_ \text {a } \_}^{2}} \times \sqrt{V V_{\text {sen } \_ \text {b } \_\mathrm{i}}^{2}}}\right)^{2} \\
& \operatorname{Sim}_{a, b}=\left(\zeta N C_{a b} \times(1-\zeta) V C_{a b}\right)
\end{aligned}
$$

dengan :

$\mathrm{NC}_{\mathrm{ab}}$ :Kemiripan semantik antara vektor kata benda(noun) kalimat $\operatorname{Sen}_{\mathrm{a}}$ dan kalimat $\operatorname{Sen}_{\mathrm{b}}$.

$\mathrm{VC}_{\mathrm{ab}}$ :Kemiripan semantik antara vektor kata kerja(verb) kalimat $\operatorname{Sen}_{a}$ dan kalimat Sen $_{\mathrm{b}}$.

$\mathrm{VV}_{\mathrm{a}}$ :Vektor kata kerja(verb) kalimat $\mathrm{Sen}_{\mathrm{a}}$.

$\mathrm{NV}_{\mathrm{a}}$ :Vektor kata benda(noun) kalimat $\mathrm{Sen}_{\mathrm{a}}$.

$\operatorname{Sim}_{\mathrm{a}, \mathrm{b}}$ :Nilai kemiripan antara kalimat $\operatorname{Sen}_{\mathrm{a}}$ dan $\operatorname{Sen}_{\mathrm{b}}$.

$\zeta \quad$ :Konstanta pengali yang menunjukkan perbandingan kontribusi kata benda dan kata kerja dalam menentukan kemiripan.

Dalam rumus diatas didefinisikan bahwa suatu kalimat dibagi menjadi satu kelompok kata $\operatorname{kerja}\left(\mathrm{S}_{-} \mathrm{V}_{\mathrm{a}}\right)$ dan satu kelompok kata benda $\left(\mathrm{S} \_\mathrm{N}_{\mathrm{a}}\right)$. Sedangkan base space kata kerja adalah gabungan dari kelompok kata kerja dari kedua kalimat. Base space kata benda adalah gabungan dari kelompok kata benda dari kedua kalimat. Vektor kata kerja $|\mathrm{VV}|$ merupakan vektor yang terbentuk dari kelompok kata kerja terhadap base space kata kerja. Vektor kata kerja dapat dihitung dari kemiripan maksimal masing-masing kata dalam kelompok kata kerja kalimat $\operatorname{Sen}_{\mathrm{a}}$ terhadap base space kata kerja menggunakan Persamaan 1. Demikian 
juga vektor kata benda $|\mathrm{NV}|$ dapat dihitung dari kemiripan maksimal masing-masing kata dalam kelompok kata benda kalimat $\mathrm{Sen}_{\mathrm{a}}$ terhadap base space kata benda.

\section{Arsitektur Sistem}

Arsitektur sistem secara keseluruhan ditunjukkan pada Gambar 2. Masukan yang diperlukan dalam proses ini adalah kode sumber dan kebutuhan fungsional. Urutan langkah kerja dari sistem yang dibangun pertama adalah membentuk kumpulan kata dalam bahasa alami dari method signature dalam kode sumber. Kumpulan kata dihasilkan melalui preproses kode sumber dan proses pengolahan bahasa alami. Kemudian menghitung kemiripan antara method signature dengan kalimat-kalimat kebutuhan fungsional. Untuk melakukan ekstraksi method siganture dari kode sumber perlu dilakukan analisa statik untuk membentuk abstract syntax tree(AST) dari kode sumber.

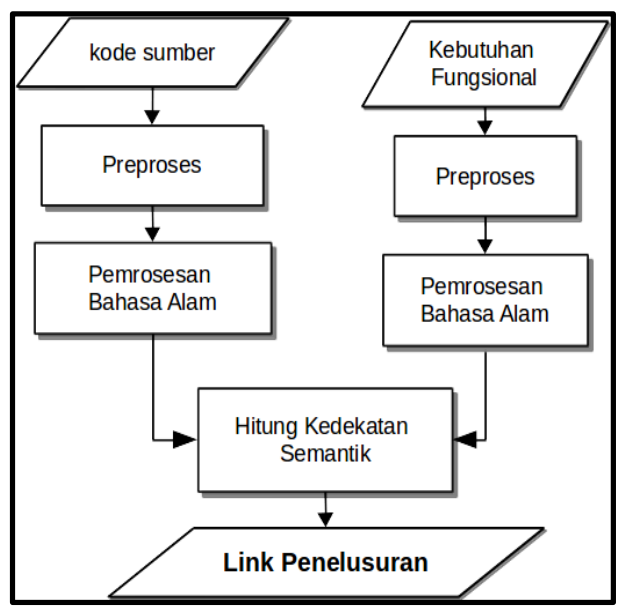

Gambar 2. Arsitektur Sistem

\subsection{Preproses Kode Sumber}

Preproses dilakukan terhadap nama package, nama class, dan method signature. Method signature terdiri dari nama method, tipe data kembalian dari method dan parameter dalam suatu method. Langkah pertama dalam preproses adalah melakukan pemisahan kata(token splitting) berdasarkan garis bawah(underscore),

CamelCase, MixedCase. Langkah kedua adalah lemmatisasi yakni mengembalikan kata ke akar katanya. Langkah berikutnya adalah menghilangkan stopwords.

Langkah berikutnya adalah melakukan ekstraksi kata dari methodsignature. Tujuan utama dalam ekstraksi kata ini adalah menemukan aksi atau operasi yang dilakukan suatu statement dalam kode sumber. Proses ini memanfaatkan POS tagger untuk menentukan kata kerja dan kata benda dalam method signature. Suatu deklarasi method terdiri dari method modifier, method return type, nama method dan parameter. Untuk mengektraksi kata dari suatu method signature digunakan aturan sebagai berikut :

1. Tipe data primitif seperti int, long, char dan tipe data bawaan kompiler akan diabaikan dalam proses ekstraksi kata dalam method signature. Jenis data bawaan kompiler seperti String, Map, List tidak akan digunakan dalam proses ekstarksi kata.

2. Dalam proses ekstraksi kata, tidak hanya nama method yang digunakan, tetapi ditambahkan juga nama class dalam method signature. Nama class pada kode sumber memberikan kontribusi dalam menentukan konteks dari aksi yang dilakukan oleh suatu method.

3. Jika terdapat kata yang sama dalam satu method signature, hanya diambil satu kali kata kemunculan kata tersebut dan mengabaikan kemunculan berikutnya.

4. Proses ekstraksi kata dari deklarasi method tidak menyertakan return type dan modifier dari suatu method.

5. Parameter suatu method juga diikutsertakan jika tidak ada kata benda dalam nama method.

6. Dalam kode sumber sering digunakan nama method yang sudah menjadi standard dan maknanya secara tekstual tidak sesuai dengan kebutuhan fungsionalnya. Nama-nama method 
tersebut misalnya actionPerformed, run, execute, fire. Nama method ini dihilangkan atau diabaikan.

7. Dalam bahasa pemrograman java ada beberapa kata yang banyak digunakan dalam nama method atau nama class yang menjadi standard penamaan dalam design pattern seperti listener, event, action, adapter, handler, singleton, factory. Kata-kata tersebut dihilangkan dari method signature.

\subsection{Preproses Kebutuhan Fungsional}

Preproses kebutuhan fungsional diawali dengan memisahkan kalimat. Akhir kalimat ditandai dengan tanda titik(.), tanda tanya(?) atau tanda seru(!). Kemudian dari masing-masing kalimat akan dihilangkan karakter nonalphanumeric. Selanjutnya dilakukan pemisahan kata berdasarkan white space(spasi).

Langkah berikutnya adalah melakukan lemmatisasi dan part of speech tagger terhadap kata-kata yang sudah dipisah. Proses lemmatisasi dan Part of Speech Tagger menggunakan library dari Stanford CoreNLP. Stanford CoreNLP menggunakan proses pipeline pengolahan bahasa alami berbasis anotasi (Manning,2014). Langkah berikutnya dalam preproses adalah menghilangkan stopwords.

\subsection{Perhitungan Kemiripan Semantik}

Hubungan semantik dihitung antara kalimat dalam kebutuhan dengan kata-kata yang dihasilkan dari pemrosesan bahasa alami terhadap method dalam kode sumber. Perhitungan kemiripan semantik dilakukan menggunakan Persamaan 4 untuk menghitung jarak antara method signature dan kebutuhan fungsional.

\section{Skenario pengujian}

Proses pengujian dilakukan dengan mengimplementasikan alur kerja yang diusulkan dan dijelaskan pada metodologi. Dalam penelitian ini dikembangkan plugin eclipse untuk membantu mempercepat proses pengujian. Plugin dikembangkan untuk membentuk dan melakukan penelusuran terhadap AST dan mengambil deklarasi method dalam semua class.

Tabel 2. Keterangan Dataset Pengujian

\begin{tabular}{|l|r|l|}
\hline $\begin{array}{c}\text { Nama } \\
\text { Aplikasi }\end{array}$ & $\begin{array}{c}\text { Jml. } \\
\text { method }\end{array}$ & \multicolumn{1}{|c|}{ Respositori } \\
\hline Itrust & 2698 & $\begin{array}{l}\text { https://sourceforge.net/proje } \\
\text { cts/itrust/ }\end{array}$ \\
\hline Gantt Project & 5292 & $\begin{array}{l}\text { https://github.com/bardsoft } \\
\text { ware/ganttproject }\end{array}$ \\
\hline
\end{tabular}

Pengujian juga dilakukan menggunakan metode yang diusulkan pada penelitian sebelumnya yaitu menggunakan Latent Semantic Analysis(LSA) (Marcus,2003) dan Latent Dirichlet Allocation(LDA)(Oliveto,2010). Hasil pengujian dengan LSA dan LDA akan dibandingkan dengan hasil pengujian menggunakan metode yang diusulkan.

\subsection{Dataset Pengujian}

Dataset untuk uji coba terdiri dari kode sumber dalam bahasa pemrograman java dan kebutuhan fungsional dari perangkat lunak tersebut. Perangkat lunak yang akan dijadikan dataset dipilih perangkat lunak kode sumber terbuka.

\subsection{Pengujian ITrust}

ITrust adalah aplikasi medis yang memiliki fitur antara lain memberikan fasilitas pada pasien untuk memantau riwayat kesehatan. Pengujian ini menggunakan kode sumber itrust versi 21.0. Pengujian untuk menghitung nilai kemiripan antara kode sumber dengan kebutuhan fungsional menggunakan metode wu-palmer dan Persamaan 4. Dengan menggunakan nilai alpha sebesar $0.4,0.5$ dan 0.6. Nilai precision hasil pengujian dengan nilai alpha 0.5 ditampilkan pada Tabel 3 dan nilai recall hasil pengujian ditampilkan pada Tabel 4 . 
Tabel 3. Nilai Precision Hasil Pengujian Itrust

\begin{tabular}{|r|r|r|r|r|r|r|}
\hline $\begin{array}{r}\text { kebutuhan } \\
\text { fungsional }\end{array}$ & \multicolumn{7}{|c|}{ treshold } \\
\hline & 0.7 & 0.75 & 0.8 & 0.85 & 0.9 & 0.95 \\
\hline 1 & 0.137 & 0.175 & 0.2 & 0.2 & 0.219 & 0.545 \\
\hline 2 & 0.423 & 0.5 & 0.5 & 0.5 & 0.524 & 0.875 \\
\hline 3 & 0.081 & 0.152 & 0.071 & 0.333 & 0.333 & 1 \\
\hline 4 & 0.227 & 0.222 & 0.167 & 0 & 0 & 0 \\
\hline 5 & 0.09 & 0.123 & 0.154 & 0.267 & 0.333 & 0 \\
\hline 6 & 0.229 & 0.229 & 0.444 & 0.333 & 0 & 0 \\
\hline 7 & 0.5 & 0.667 & 1 & 1 & 1 & 1 \\
\hline 8 & 0.053 & 0.185 & 0.333 & 0.6 & 0.667 & 1 \\
\hline 9 & 0.027 & 0.032 & 0.065 & 0.222 & 0.667 & 0.667 \\
\hline 10 & 0.19 & 0.444 & 0.286 & 0.286 & 0.333 & 0 \\
\hline 11 & 0.03 & 0.053 & 0.111 & 0.2 & 0.25 & 1 \\
\hline 12 & 0.1 & 0.106 & 0.159 & 0.212 & 0.091 & 0.182 \\
\hline 13 & 0.25 & 0.429 & 0.6 & 0.6 & 0.667 & 1 \\
\hline 14 & 0.088 & 0.136 & 0.14 & 0.153 & 0.164 & 0.27 \\
\hline 15 & 0.167 & 0.222 & 0.333 & 0.429 & 0.5 & 0 \\
\hline 16 & 0.889 & 0.875 & 1 & 1 & 1 & 0 \\
\hline rata-rata & 0.218 & 0.284 & 0.348 & 0.396 & 0.422 & 0.471 \\
\hline & & & & & & \\
\hline
\end{tabular}

Sebagai pembanding dilakukan percobaan terhadap dataset yang sama menggunakan LDA dan LSA. Hasil nilai precision dari percobaan menggunakan LSA dan LDA ditunjukkan pada Tabel 5 dan nilai recall ditunjukkan pada Tabel 6 .

Tabel 4. Nilai Recall Hasil Pengujian Itrust

\begin{tabular}{|r|r|r|r|r|r|r|}
\hline $\begin{array}{r}\text { kebutuhan } \\
\text { fungsional }\end{array}$ & \multicolumn{6}{|c|}{ treshold } \\
\hline & 0.7 & 0.75 & 0.8 & 0.85 & 0.9 & 0.95 \\
\hline 1 & 0.778 & 0.778 & 0.778 & 0.778 & 0.778 & 0.667 \\
\hline 2 & 0.647 & 0.647 & 0.647 & 0.647 & 0.647 & 0.412 \\
\hline 3 & 0.438 & 0.313 & 0.063 & 0.063 & 0.063 & 0.063 \\
\hline 4 & 0.714 & 0.286 & 0.143 & 0 & 0 & 0 \\
\hline 5 & 0.867 & 0.667 & 0.4 & 0.267 & 0.267 & 0 \\
\hline 6 & 0.857 & 0.571 & 0.286 & 0.036 & 0 & 0 \\
\hline 7 & 0.4 & 0.4 & 0.4 & 0.2 & 0.2 & 0.2 \\
\hline 8 & 0.625 & 0.625 & 0.5 & 0.375 & 0.25 & 0.25 \\
\hline
\end{tabular}

\begin{tabular}{|r|r|r|r|r|r|r|}
\hline 9 & 0.429 & 0.286 & 0.286 & 0.286 & 0.286 & 0.286 \\
\hline 10 & 0.667 & 0.667 & 0.333 & 0.333 & 0.333 & 0 \\
\hline 11 & 0.4 & 0.4 & 0.2 & 0.2 & 0.2 & 0.2 \\
\hline 12 & 0.816 & 0.579 & 0.474 & 0.368 & 0.079 & 0.053 \\
\hline 13 & 0.429 & 0.429 & 0.429 & 0.429 & 0.286 & 0.143 \\
\hline 14 & 0.824 & 0.706 & 0.706 & 0.647 & 0.588 & 0.588 \\
\hline 15 & 0.588 & 0.471 & 0.353 & 0.353 & 0.176 & 0 \\
\hline 16 & 0.727 & 0.636 & 0.636 & 0.636 & 0.636 & 0 \\
\hline rata-rata & 0.638 & 0.529 & 0.415 & 0.351 & 0.299 & 0.179 \\
\hline
\end{tabular}

Tabel 5. Nilai Precision Hasil Pengujian Itrust dengan metode LSA dan LDA

\begin{tabular}{|l|r|r|r|r|r|r|}
\hline \multirow{2}{*}{} & \multicolumn{6}{|c|}{ treshold } \\
\cline { 2 - 7 } & 0.7 & 0.75 & 0.8 & 0.85 & 0.9 & 0.95 \\
\hline LSA & 0.15 & 0.046 & 0.058 & 0.021 & 0.022 & 0.016 \\
\hline LDA & $\begin{array}{r}0.28 \\
4\end{array}$ & 0.305 & 0.292 & 0.298 & 0.23 & 0.093 \\
& & & & & \\
\hline
\end{tabular}

Tabel 6. Nilai Recall Hasil Pengujian Itrust dengan metode LSA dan LDA

\begin{tabular}{|l|r|r|r|r|r|r|}
\hline \multirow{2}{*}{} & \multicolumn{5}{|c|}{ treshold } \\
\cline { 2 - 7 } & 0.7 & 0.75 & 0.8 & 0.85 & 0.9 & 0.95 \\
\hline LSA & 0.149 & 0.102 & 0.086 & 0.047 & 0.047 & 0.023 \\
\hline LDA & 0.265 & 0.236 & 0.21 & 0.19 & 0.159 & 0.048 \\
\hline
\end{tabular}

Hasil pengujian menggunakan metode LDA menghasilkan nilai precision sebesar 0.305 pada recall 0.23 . Pada kasus ini nilai tersebut tercapai pada iterasi 2000 dengan jumlah topik 100 dan ambang batas 0.75 . Metode LSA menghasilkan precision sebesar 0.15 pada recall 0.15 . Pada kasus Itrust, metode LDA menghasilkan precision dan recall lebih baik dari pada LSA. Perbandingan precision antara metode kemiripan dalam penelitian ini dengan LDA ditunjukkan pada grafik Gambar 3 dan perbandingan nilai recall pada Gambar 4. 


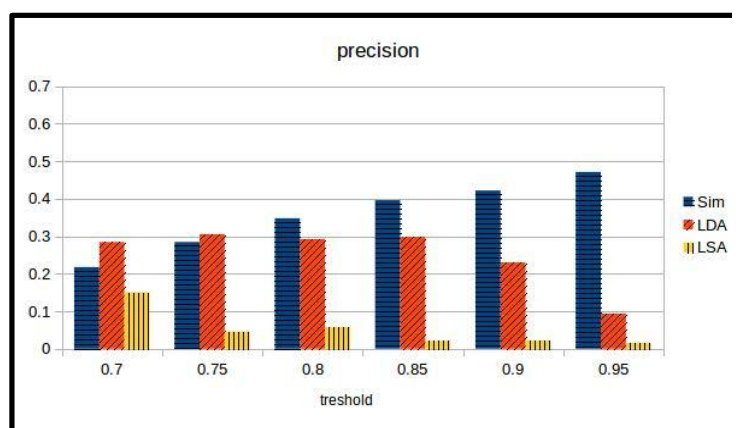

Gambar 3. Grafik Perbandingan Nilai Precision Itrust

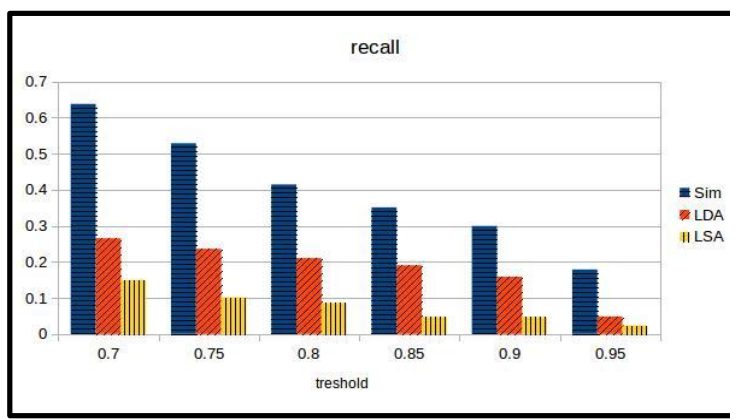

Gambar 4. Grafik Perbandingan Nilai Recall Itrust

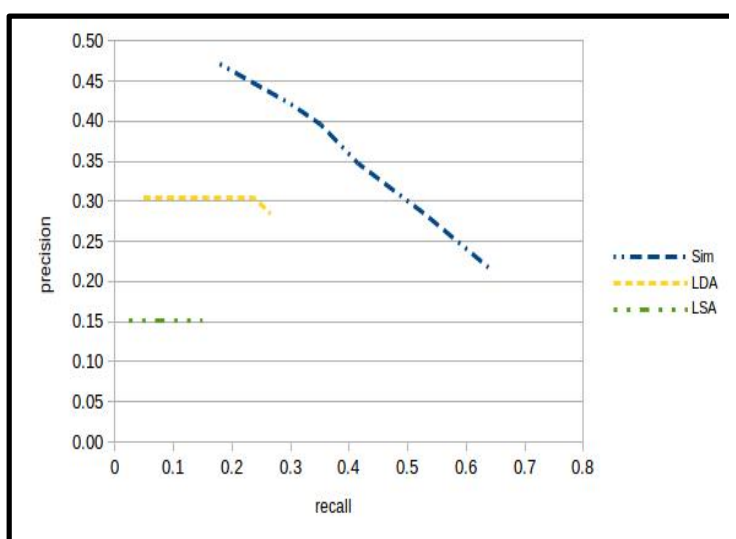

Gambar 5. Grafik Nilai Interpolasi Itrust

Gambar 5 menunjukkan kurva interpolasi precision recall hasil pengujian. Metode penelusuran menggunakan Sim menghasilkan nilai precision tertinggi 0.47 pada recall 0.18 tapi nilai precision-nya terus menurun dengan meningkatnya recall.

\subsection{Pengujian Gantt Project}

Gantt Project adalah aplikasi pengelolaan proyek sederhana yang ditulis menggunakan bahasa pemrograman java dan bersifat kode terbuka. Fitur yang dimiliki meliputi fungsi dasar pengelolaan proyek seperti gantt chart, penjadwalan dan pengelolaan sumber daya manusia. Pada penelitian ini digunakan kode sumber versi 2.7.1.

Kode sumber Gantt Project terdiri dari 520 class dengan jumlah method sebanyak 5292 method. Nilai precision hasil pengujian dengan nilai alpha 0.4 ditampilkan pada Tabel 7 dan nilai recall hasil pengujian ditampilkan pada Tabel 8 .

Tabel 7. Nilai Precision Hasil Pengujian Gantt Project

\begin{tabular}{|r|r|r|r|r|r|r|}
\hline $\begin{array}{r}\text { kebutuhan } \\
\text { fungsional }\end{array}$ & \multicolumn{7}{|c|}{ treshold } \\
\hline & 0.7 & 0.75 & 0.8 & 0.85 & 0.9 & 0.95 \\
\hline 1 & 0.018 & 0.03 & 0.06 & 0.053 & 0.097 & 0.104 \\
\hline 2 & 0.178 & 0.271 & 0.579 & 1 & 1 & 0 \\
\hline 3 & 0.031 & 0.071 & 0.211 & 0.24 & 0.208 & 0.238 \\
\hline 4 & 0.292 & 0.35 & 0.579 & 0.889 & 0.889 & 1 \\
\hline 5 & 0.009 & 0.019 & 0.03 & 0.088 & 0.241 & 0 \\
\hline 6 & 0.025 & 0.058 & 0.273 & 0.5 & 0 & 0 \\
\hline rata-rata & 0.092 & 0.133 & 0.289 & 0.462 & 0.406 & 0.224 \\
\hline & & & & & & \\
\hline
\end{tabular}

Tabel 8. Nilai Recall Hasil Pengujian Gantt Project

\begin{tabular}{|r|r|r|r|r|r|r|}
\hline $\begin{array}{c}\text { kebutuhan } \\
\text { fungsional }\end{array}$ & \multicolumn{7}{|c|}{ treshold } \\
\hline & 0.7 & 0.75 & 0.8 & 0.85 & 0.9 & 0.95 \\
\hline 1 & 0.588 & 0.588 & 0.529 & 0.353 & 0.353 & 0.294 \\
\hline 2 & 0.533 & 0.433 & 0.367 & 0.333 & 0.2 & 0 \\
\hline 3 & 0.846 & 0.769 & 0.615 & 0.462 & 0.385 & 0.385 \\
\hline 4 & 0.95 & 0.7 & 0.55 & 0.4 & 0.4 & 0.3 \\
\hline 5 & 0.421 & 0.421 & 0.368 & 0.368 & 0.368 & 0 \\
\hline 6 & 0.6 & 0.6 & 0.6 & 0.6 & 0 & 0 \\
\hline rata-rata & 0.656 & 0.585 & 0.505 & 0.419 & 0.284 & 0.163 \\
\hline & & & & & & \\
\hline
\end{tabular}

Hasil nilai precision dari percobaan menggunakan LSA dan LDA ditunjukkan pada Tabel 9 dan nilai recall ditunjukkan pada Tabel 10. Hasil pengujian menggunakan metode LDA menghasilkan 
nilai precision sebesar 0.078 pada recall 0.372 . Pada kasus ini nilai tersebut tercapai pada iterasi 2000 dengan jumlah topik 100 dan ambang batas 0.70. Metode LSA menghasilkan precision sebesar 0.167 pada recall 0.014 .

Tabel 9. Nilai Precision Hasil Pengujian Gantt Project dengan Metode LSA dan LDA

\begin{tabular}{|l|r|r|r|r|r|r|}
\hline \multirow{2}{*}{} & \multicolumn{6}{|c|}{ treshold } \\
\cline { 2 - 7 } & 0.7 & 0.75 & 0.8 & 0.85 & 0.9 & 0.95 \\
\hline LSA & 0.159 & 0.125 & 0.139 & 0.167 & 0.167 & 0 \\
\hline LDA & 0.078 & 0.068 & 0.062 & 0.051 & 0.02 & 0.02 \\
\hline
\end{tabular}

Tabel 10. Nilai Recall Hasil Pengujian Gantt Project dengan Metode LSA dan LDA

\begin{tabular}{|l|r|r|r|r|r|r|}
\hline \multirow{2}{*}{} & \multicolumn{6}{|c|}{ treshold } \\
\cline { 2 - 7 } & 0.7 & 0.75 & 0.8 & 0.85 & 0.9 & 0.95 \\
\hline LSA & 0.028 & 0.014 & 0.014 & 0.014 & 0.008 & 0 \\
\hline LDA & 0.372 & 0.298 & 0.25 & 0.127 & 0.05 & 0.042 \\
\hline
\end{tabular}

Pada kasus Gantt Project, metode LSA menghasilkan nilai precision lebih tinggi daripada LDA.Tetapi pada titik potong 0.95 LSA tidak menemukan traceability link, nilai precision yang dihasilkan 0 . Nilai recall LSA sangat kecil, nilai recall tertinggi 0.028. Perbandingan precision antara metode kemiripan dalam penelitian ini dengan LDA ditunjukkan pada grafik Gambar 6 dan perbandingan nilai recall pada Gambar 7.Kurva interpolasi precision recall hasil pengujian ditunjukkan pada Gambar 8. Metode penelusuran menggunakan Sim menghasilkan nilai precision 0.46 sampai pada rentang recall 0.41 . Sedangkan LDA hanya mencapai nilai precision 0.08 sampai rentang recall 0.37. Dalam kasus Gantt Project kemiripan method signature memberikan hasil precision dan recall lebih baik daripada LDA.

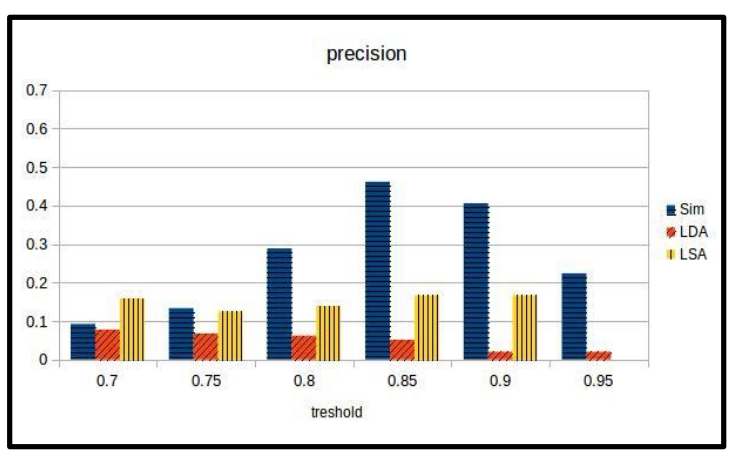

Gambar 6. Grafik Perbandingan Nilai Precision Gantt Project

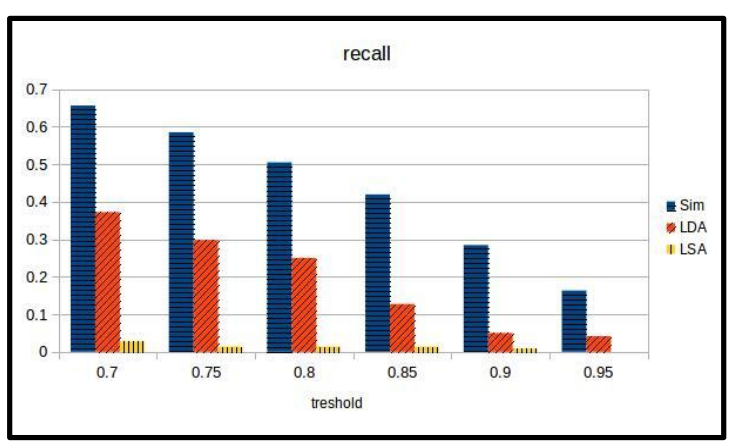

Gambar 7. Grafik Perbandingan Nilai Recall Gantt Project

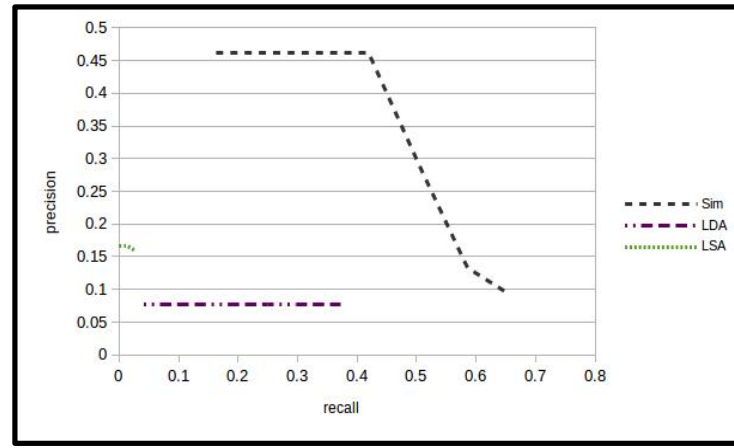

Gambar 8. Kurva Interpolasi Precision dan Recall Gantt Project

\subsection{Analisa dan Pembahasan}

Pada kebutuhan fungsional yang memiliki kalimat dengan kata pelengkap atau objek tidak langsung(Indirect Object) seperti "Add resource assignment to Task", dimana "task" merupakan kata pelengkap, memiliki nilai kemiripan yang rendah karena parsing pada method hanya menghasilkan kata kerja dan objek(Direct Object/DO). Pada kalimat paralel seperti "an email will be sent after the data is stored", sistem tidak bisa menemukan link penelusuran. Kalimat paralel memiliki kata penghubung, dua kata benda dan dua kata 
kerja. Parsing method signature hanya menghasilkan satu kata kerja dan satu kata benda sehingga nilai kemiripannya sangat kecil.

\section{Kesimpulan dan Saran}

Beberapa kesimpulan yang dapat ditarik dari hasil pengerjaan penelitian ini adalah hasil pengujian menunjukkan metode kemiripan method signature memberikan hasil nilai precision dan recall lebih baik daripada metode LSA dan LDA. Saran-saran untuk penelitian mendatang antara lain hasil pengujian pada beberapa kebutuhan fungsional tidak menemukan link penelusuran karena kecilnya nilai kemiripan. Salah satu penyebabnya karena struktur kalimat kebutuhan fungsional seperti kalimat paralel dan adanya objek tidak langsung(Indirect Object) dalam kalimat. Perlu dilakukan parsing struktur kalimat kebutuhan fungsional untuk meningkatkan akurasi.

\section{Referensi}

[1] Abadi, A., Nisenson, M., Simionovici, Y. (2008), "A traceability technique for specifications", Proceedings of 16th IEEE International Conference on Program Comprehension, hal. 103112.

[2] Antoniol, G., Canfora, G., Casazza, G., De Lucia, A., Merlo, E.(2000), "Tracing Object-Oriented Code into Functional Requirements", Proceedings of 8th International Workshop on Program Comprehension (IWPC'00), hal. 7987.

[3] Eaddy, M., Aho, A., Antoniol, G., Guéhéneuc, Y.-G. (2008), "Cerberus: Tracing requirements to source code using information retrieval dynamic analysis and program analysis", Proceedings of 16th IEEE International Conference on Program Comprehension, hal. 53-62.

[4] Fellbaum, C. (1998), “WordNet: An
Electronic Lexical Database", MIT Press, Cambridge.

[5] Gotel O., Finkelstein, A. (1994), "An analysis of the requirements traceability problem", Proceedings of 1 st International Conference on Requirements Engineering, hal. 94101.

[6] Hayashi, S., Yoshikawa, T., Saeki, M. (2010), "Sentence-to-Code Traceability Recovery with Domain Ontologies," Proceedings of 2010 Asia Pacific Software Engineering Conference, hal. 385-394.

[7] Mahmoud, A., Nan Niu, Songhua Xu (2012), "A semantic relatedness approach for traceability link recovery", proceedings of 20th International Conference on Program Comprehension, Passau, hal. 183 192.

[8] Manning, Christopher D., Mihai Surdeanu, John Bauer, Jenny Finkel, Steven J. Bethard, and David McClosky. 2014. "The Stanford CoreNLP Natural Language Processing Toolkit", Proceedings of the 52nd Annual Meeting of the Association for Computational Linguistics: System Demonstrations, pp. 55-60.

[9] Marcus, A., Maletic, J.I. (2003), "Recovering Documentation-toSource-Code Traceability Links using Latent Semantic Indexing", Proceeding International Conf. on Software Engineering, hal. 125-135.

[10] Miller, G.A. (1995), "WordNet: A Lexical Database for English", Communications of the ACM, Vol. 38, No. 11, hal.39-41.

[11] Ming Che Lee (2011), "A novel sentence similarity measure for semantic-based expert systems", Expert Systems with Applications, Vol. 38, Issue 5, hal 6392-6399.

[12] Oliveto, R., Gethers, M., Poshyvanyk, D., De Lucia, A. (2010), "On the equivalence of information retrieval 
methods for automated traceability link recovery", Proceedings of Int. Conf. Program Comprehension, hal. 68-71.

[13] Shepherd, D., Fry, Z.P., Hill, E., Pollock, L., Vijay-Shanker, K. (2007), "Using natural language program analysis to locate and understand action-oriented concerns", Proceeding of 6th International Conference on Aspect-Oriented Software Development(AOSD), hal. 212-224.

[14] Sridhara, G., Hill, E., Pollock, L., Vijay-Shanker, K. (2008), "Identifying Word Relations in Software: A Comparative Study of Semantic Similarity Tools", proceedings of 16th IEEE International Conference on Program Comprehension, Amsterdam, hal. 123 $-132$.

[15] Wu, Z., \& Palmer, M. (1994), "Verbs semantics and lexical selection", Proceedings of the 32nd annual meeting on Association for Computational Linguistics, hal. 133138. 